\title{
Map of Landslides Triggered by the January 12, 2010, Haiti Earthquake
}

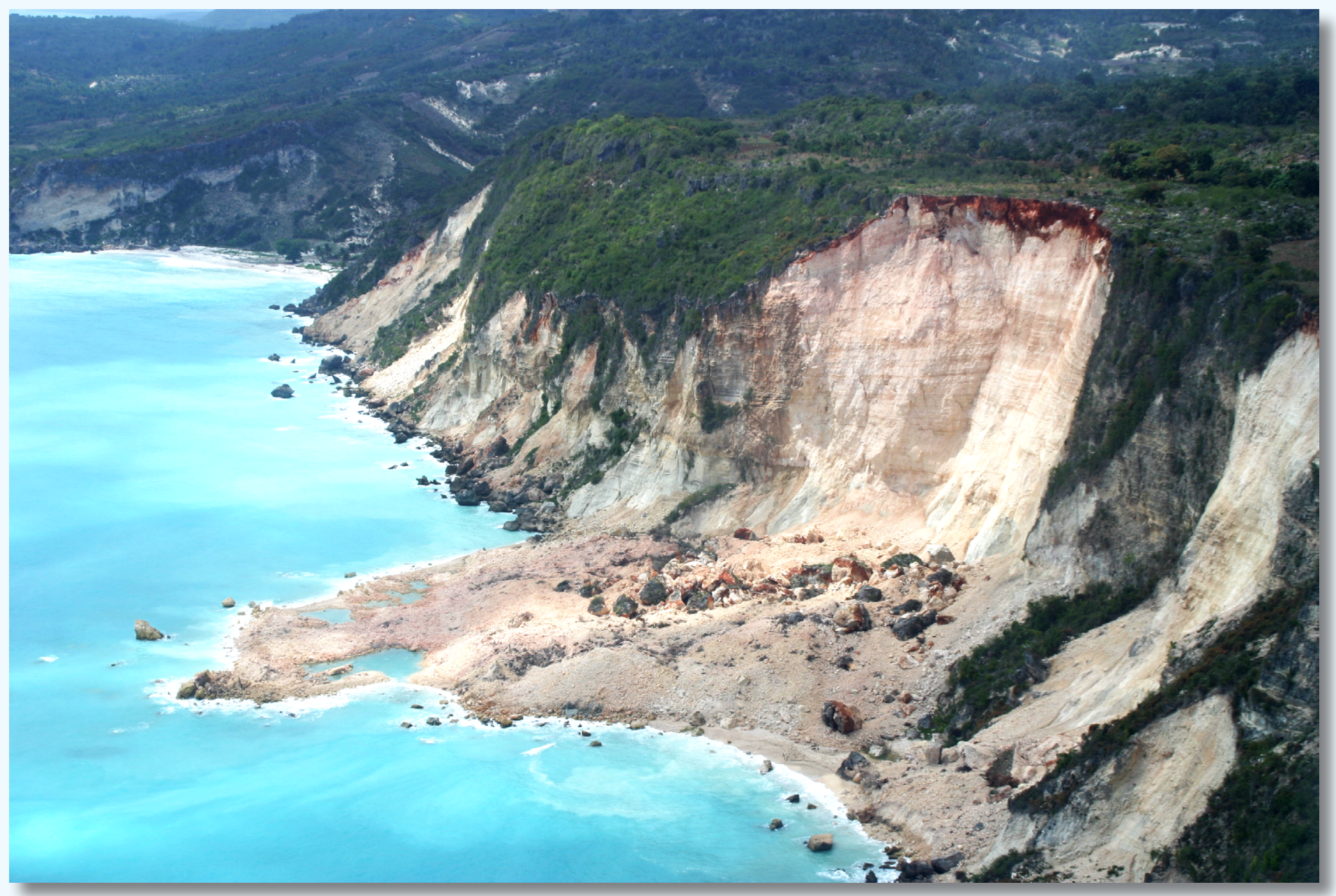

Pamphlet to accompany

Scientific Investigations Map 3353

U.S. Department of the Interior

U.S. Geological Survey 
Cover. Landslides triggered by the 2010 Haiti earthquake. Photograph by R.W. Jibson, March 2010. 


\section{Map of Landslides Triggered by the January 12, 2010, Haiti Earthquake}

By Edwin L. Harp, Randall W. Jibson, and Robert G. Schmitt

Pamphlet to accompany

Scientific Investigations Map 3353 


\title{
U.S. Department of the Interior SALLY JEWELL, Secretary
}

\section{U.S. Geological Survey Suzette M. Kimball, Director}

\author{
U.S. Geological Survey, Reston, Virginia: 2016
}

For more information on the USGS - the Federal source for science about the Earth, its natural and living resources, natural hazards, and the environment—visit http://www.usgs.gov or call 1-888-ASK-USGS.

For an overview of USGS information products, including maps, imagery, and publications, visit http://www.usgs.gov/pubprod/.

Any use of trade, firm, or product names is for descriptive purposes only and does not imply endorsement by the U.S. Government.

Although this information product, for the most part, is in the public domain, it also may contain copyrighted materials as noted in the text. Permission to reproduce copyrighted items must be secured from the copyright owner.

Suggested citation:

Harp, E.L., Jibson, R.W., and Schmitt, R.G., 2016, Map of landslides triggered by the January 12, 2010, Haiti earthquake: U.S. Geological Survey Scientific Investigations Map 3353, 15 p., 1 sheet, scale 1:150,000, http://dx.doi.org/10.3133/sim3353.

ISSN 2329-132X (online) 


\section{Contents}

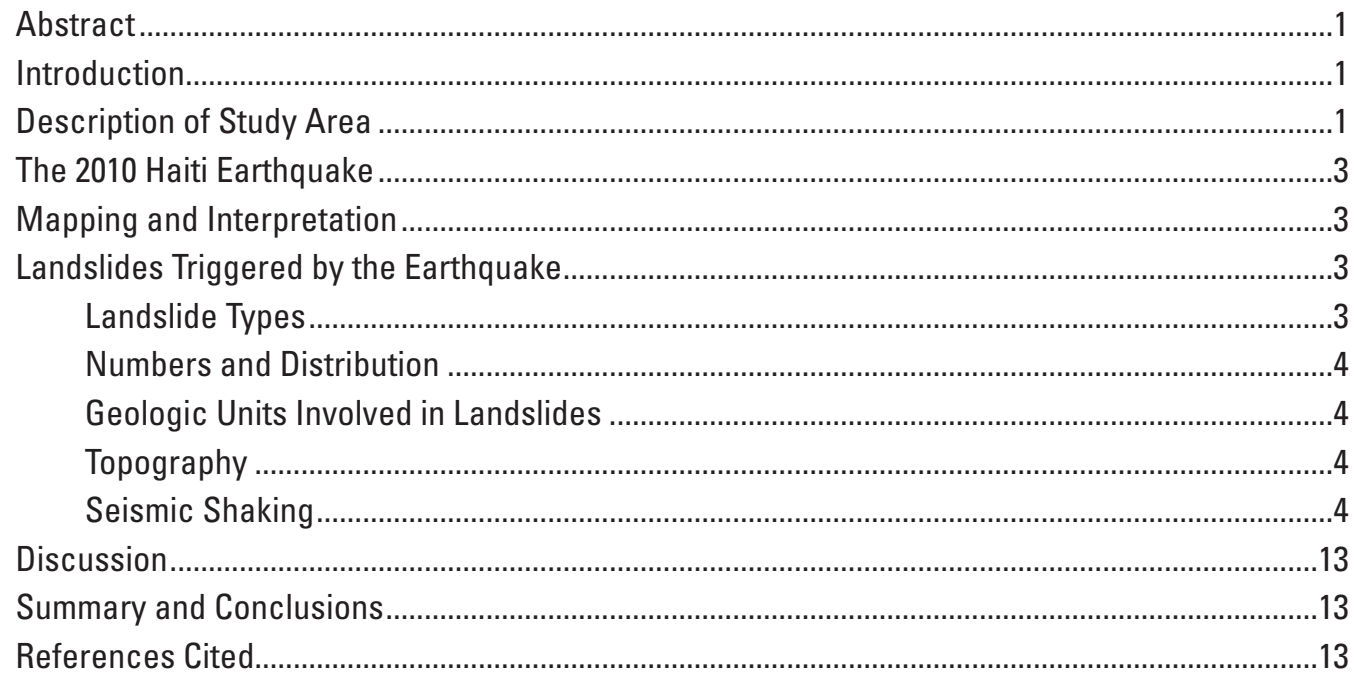

\section{Sheet}

1. Landslides triggered by the January 12,2010 , Haiti earthquake ................................. link

\section{Figures}

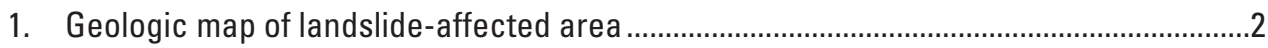

2. Map of landslide concentration $\left(\right.$ percent $/ \mathrm{km}^{2}$ ) in the landslide-affected area..................5

3. Rock fall composed of lower Miocene limestone boulders that have failed along preexisting fractures .................................................................................................

4. Shallow soil slides in weathered volcanic regolith within the Enriquillo-Plantain Garden fault zone..........................................................................................................

5. Histograms of triggered landslides with respect to geology and slope .............................

6. Detail of fault-slip model of Hayes and others (2010) on map showing landslides

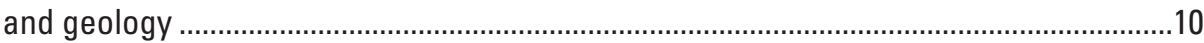

7. Detail of fault-slip model of Symithe and others (2013) on map showing landslides

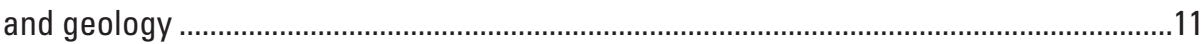

8. Map of landslide densities overlain by ShakeMap contours of PGA (peak ground acceleration) from the earthquake.

\section{Tables}

1. Areal distribution of earthquake-triggered landslides within geologic units....................7

2. Areal distribution of earthquake-triggered landslide for different rock types ..................9 


\section{Conversion Factors}

International System of Units to Inch/Pound

\begin{tabular}{|c|c|c|}
\hline Multiply & By & To obtain \\
\hline \multicolumn{3}{|c|}{ Length } \\
\hline meter $(\mathrm{m})$ & 3.281 & foot $(\mathrm{ft})$ \\
\hline kilometer (km) & 0.6214 & mile (mi) \\
\hline \multicolumn{3}{|c|}{ Area } \\
\hline square kilometer $\left(\mathrm{km}^{2}\right)$ & 0.3861 & square mile $\left(\mathrm{mi}^{2}\right)$ \\
\hline \multicolumn{3}{|c|}{ Volume } \\
\hline cubic meter $\left(\mathrm{m}^{3}\right)$ & 1.308 & cubic yard $\left(\mathrm{yd}^{3}\right)$ \\
\hline
\end{tabular}

\section{Datum}

Coordinate information is referenced to the World Geodetic System 1984 (WGS 84).

\section{Abbreviations}

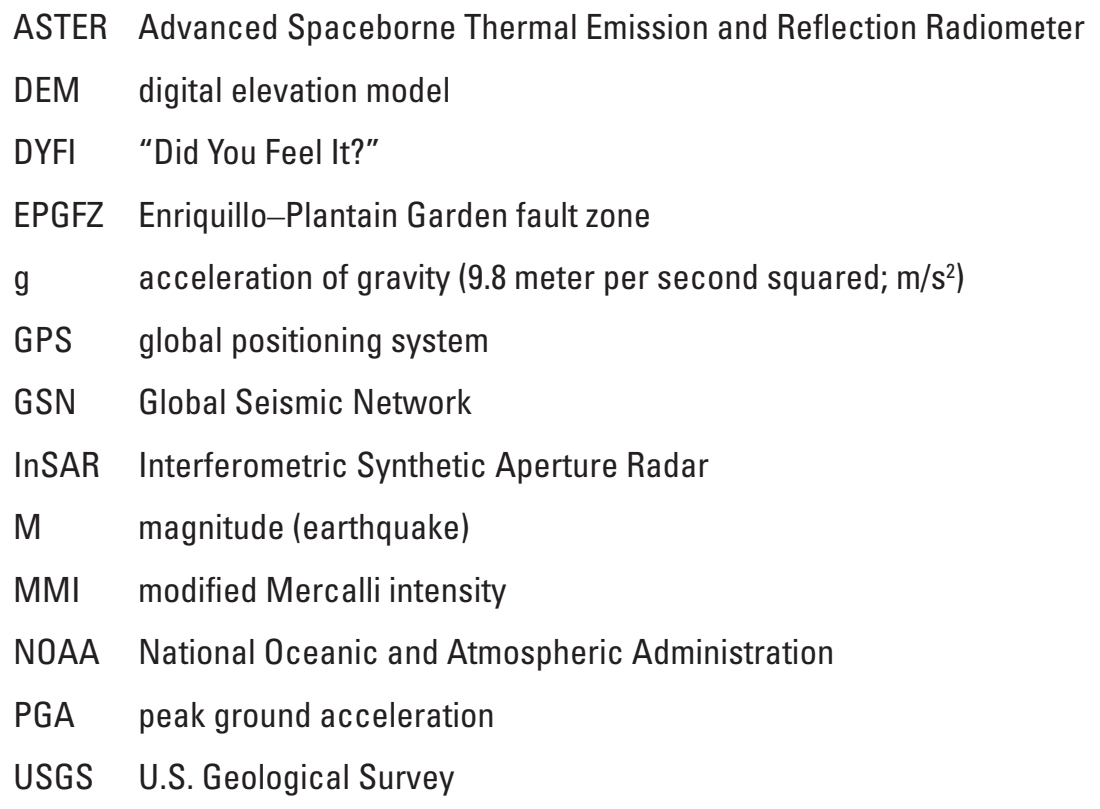




\title{
Map of Landslides Triggered by the January 12, 2010, Haiti Earthquake
}

\author{
By Edwin L. Harp, Randall W. Jibson, and Robert G. Schmitt
}

\section{Abstract}

The magnitude (M) 7.0 Haiti earthquake of January 12, 2010, triggered landslides throughout much of Haiti on the island of Hispaniola in the Caribbean Sea. The epicenter of the quake was located at $18.44^{\circ} \mathrm{N}$., $72.57^{\circ} \mathrm{W}$. at a depth of 13 kilometers $(\mathrm{km})$ approximately $25 \mathrm{~km}$ southwest of the capital, Port-au-Prince. Although estimates vary widely, the most reliable surveys of casualties indicate that the earthquake caused 158,679 fatalities and more than 300,000 injuries. The U.S. Geological Survey compared publicly available satellite imagery acquired both before and after the earthquake and mapped 23,567 landslides that were triggered by the strong shaking. Our mapping from aerial photography and satellite imagery was augmented by field observations.

Most of the landslides triggered by the earthquake were south of the Léogâne fault on the footwall and were fairly shallow falls and slides in weathered limestone (2-5 meters $[\mathrm{m}]$ thick) and volcanic rock and soil (generally $<1 \mathrm{~m}$ thick). Landslides extended from the north to the south coasts of the southwestern peninsula (southwest of Port-au-Prince) and almost $60 \mathrm{~km}$ to the east and west of the epicenter. The highest concentration of landslides was on the steep limestone slopes of incised river valleys, but large numbers of landslides also occurred on gentler slopes in weathered volcanic rocks. Although some high landslide concentrations did occur near areas of maximum fault slip, the overall distribution of landslides appears to involve complex interactions between geology, topography, and strong shaking with limited spatial correlation between fault slip and landslides.

\section{Introduction}

The January 12, 2010, Haiti earthquake (magnitude [M] 7.0) caused widespread damage and casualties. Haiti is located on the western one-third of the island of Hispaniola in the Caribbean Sea. One of the most prevalent effects of this earthquake was the triggering of tens of thousands of landslides from steep slopes throughout much of the country. Documenting the distribution and concentration of these landslides is important to understand the geologic, seismologic, and topographic factors that control this distribution; such information is important for assessing future landslide hazards in both Haiti and elsewhere.

Using a combination of pre- and post-earthquake satellite imagery and aerial photography, we mapped 23,567 landslides triggered by the earthquake within an area of about 5,000 square kilometers $\left(\mathrm{km}^{2}\right)$ (see map sheet). Most of the landslides triggered by the earthquake were south (on the footwall) of the seismogenic Léogâne fault, a blind thrust fault not exposed at the ground surface. Two other inventories of landslides triggered by this earthquake have been produced: Gorum and others (2013) mapped 4,490 landslides, and Xu and others (2014) mapped 30,828 landslides. Both of these inventories were produced solely by interpretation of imagery, whereas our mapping from aerial photography and satellite imagery was augmented by our field investigation in March 2010. Differences in numbers of landslides in these inventories probably stem from differences in (1) the extent of the areas examined, (2) the quality and resolution of remotely sensed imagery used, (3) how coalescing landslides from multiple sources are counted, and (4) subjective interpretation of features visible in the imagery.

In this report, we present a map and a data file of triggered landslides (as polygons); we briefly describe the 2010 earthquake and describe the landslide distribution with respect to geology, topography, and strong shaking.

\section{Description of Study Area}

Haiti occupies the western one-third of the island of Hispaniola. Haiti's terrain consists primarily of rugged mountains interspersed with narrow river valleys and small coastal plains. Elevations range from sea level up to 2,680 meters (m). The climate is tropical, with average annual rainfall of about 1,440 millimeters (mm) (http://mecometer.com/whats/haiti/ average-yearly-precipitation/).

A geologic map of the study area (fig. 1) shows that the central mountainous core of the southern peninsula consists of Cretaceous andesitic and basaltic basement rock and Cretaceous-Tertiary limestone and clastic sedimentary rock. Quaternary deposits include alluvium deposited in the PortAu-Prince valley and interior incised river valleys, alluvial 


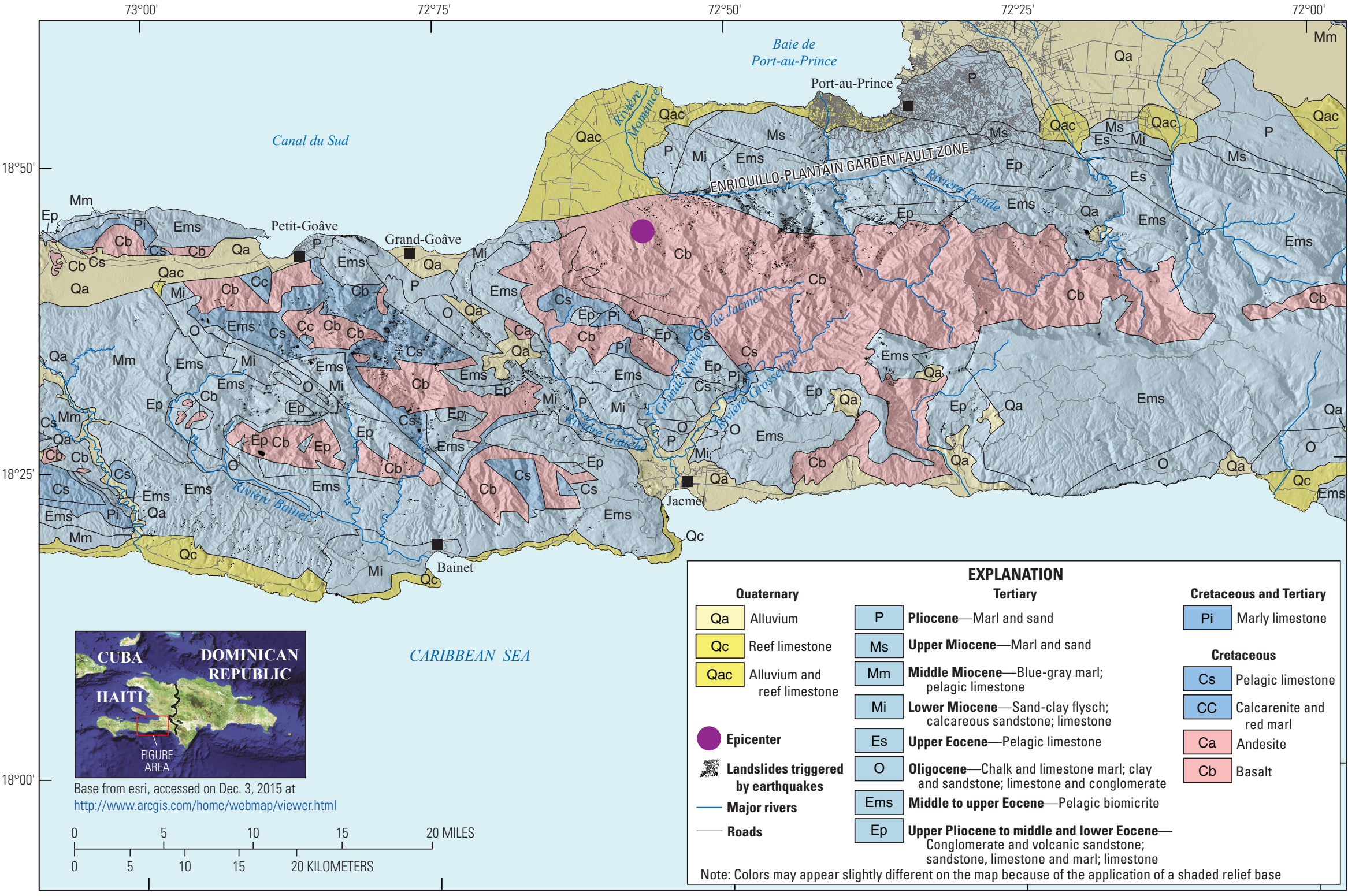

Base map data from a variety of sources (see pamphet). accesed from http//hdds usgs gov/ between January 2013 and January 2014

Projection: Universal Transverse Mercator, zone 18; World Geodetic System 1984 (WGS 84): False easting 500000.0, false northing 0.0, central meridian -75.0

Figure 1. Geologic map of landslide-affected area. Colors are used to group units broadly by lithology and age. Volcanic rocks (red); calcareous rocks (blue); and alluvium (tan). From Bureau des Mines et de l'Energie (2005). 
fan and colluvial wedge deposits along the margins of larger valleys, and coastal delta fan complexes where larger rivers discharge into the sea along the coast.

The 2010 earthquake occurred near the EnriquilloPlaintain Garden fault zone (EPGFZ), a major left-lateral fault zone that defines part of the boundary between the Caribbean and North American tectonic plates. The plate boundary accommodates an average of 20 millimeters per year $(\mathrm{mm} / \mathrm{yr})$ of left-lateral displacement between the plates (U.S. Geological Survey, 2010a). The fault extends east-west along the north part of the southern Haiti peninsula and has exerted a substantial geomorphic influence on the region. Continuing strike-slip fault displacement has formed linear valleys and bounding uplifted mountains, shutter ridges, and sag ponds along the fault trace. Some river valleys, most strikingly the deep valley of the Rivière Momance, follow the EPGFZ trace and are apparently the result of preferred incision of sheared and locally weaker rocks along the fault zone.

\section{The 2010 Haiti Earthquake}

On January 12, 2010, an M7.0 earthquake struck approximately $25 \mathrm{~km}$ southwest of the capital of Haiti, Port-au-Prince, at 16:53 local time. The epicenter of the quake was located at $18.44^{\circ} \mathrm{N} ., 72.57^{\circ} \mathrm{W}$. at a depth of $13 \mathrm{~km}$ (U.S. Geological Survey, 2010a). Although estimates vary widely, the most reliable surveys of casualties indicate that the earthquake caused 158,679 fatalities (Kolbe and others, 2010) and more than 300,000 injuries (Cavallo and others, 2010). The earthquake was initially attributed to displacement within the left-lateral EPGFZ. However, joint inversion of Interferometric Sythetic Aperature Radar (InSAR) data, coastal uplift/subsidence from global positioning system (GPS) data, and teleseismic body waves (Calais and others, 2010; Hayes and others, 2010; Symithe and others, 2013) indicated that the preferred model of fault slip involves complex movement on as many as three faults, with about 80 percent of the moment released from movement on a $55^{\circ}$ north-dipping blind thrust called the Léogâne fault (Hayes and others, 2010) located just to the north of the EGPFZ.

No strong-motion records are available from the earthquake. The U.S. Geological Survey (2010b) ShakeMap model, described in detail subsequently, estimated that peak ground accelerations (PGA) exceeded 0.9 acceleration of gravity (g) near the epicenter (Worden and others, 2010).

\section{Mapping and Interpretation}

We acquired imagery after the earthquake from a variety of sources (all of the imagery was accessed through the U.S. Geological Survey [USGS] at http://hdds.usgs.gov/) including the following: Google Earth; Digital Globe's Quickbird, Geoeye, and Worldview 2; National Oceanographic and
Atmospheric Administration (NOAA) aerial photography; and Microsoft Ultracam G aerial photography. All of this imagery has a resolution of less than $1 \mathrm{~m}$. Google Earth posted many different sources of imagery including their own. The highest resolution and best true color was from Google Earth's aerial photography taken on January 24, 2010. Its resolution is about $0.3 \mathrm{~m}$, but its coverage is limited. We eventually settled on using the Microsoft Ultracam G aerial photographs taken on January 28, 2010, because of its high resolution (approximately $0.6 \mathrm{~m}$ ), complete coverage of the country, near-vertical view, and advantage of being largely free of clouds. This imagery allowed us to thoroughly map all landslides triggered by the earthquake and achieve mapping consistency throughout the study area. Where possible, we compared pre- and post-earthquake imagery to confirm our interpretations of coseismic triggering. In some places, especially in the southeastern part of the study area, preearthquake imagery was not available. In March 2010, we carried out helicopter reconnaissance of the landslide-affected area in Haiti and conducted ground surveys of significant landslides (Jibson and Harp, 2011).

The imagery used was imported into esri's ArcMap10.1 and ArcGlobe 10.1. We identified the landslides and mapped them as polygons by digitizing them in ArcMap; the polygons were then transferred into ArcGlobe, where the imagery was draped onto a 30-m digital elevation model (DEM; ASTER Global DEM, resolution 1 arc-second for scene: ASTGDEMV2_0N18W073, accessed October 2011, and available at https://lpdaac.usgs.gov/dataset_discovery/aster/aster_ products_table/astgtm). The polygons could then be viewed in a pseudo-three-dimensional perspective, which aided in the identification of landslides and the interpretations of the topography of surrounding slopes. The earthquake-triggered landslides generally appeared lighter in color than the surrounding slopes (especially within the limestone terrain); landslides commonly displayed fresh-looking cracks at the main scarps in the source areas and abundant fine particles and even dust at many of the distal areas beyond the landslide toes. Each polygon includes all of the landslide features (source, travel path, and deposit); no attempt was made to separate these features.

\section{Landslides Triggered by the Earthquake}

\section{Landslide Types}

The most common types of landslides triggered by the earthquake were shallow, disrupted rock falls and rock slides (landslide terminology after Varnes, 1978; and Keefer, 1984) in limestone and highly weathered volcanic rocks, primarily basalt and andesite (Harp and others, 2013). In addition to shallow rock falls and rock slides, the earthquake triggered less numerous, deeper rotational slumps, rock-block slides, and earth flows, some of which blocked drainages and formed small, temporary lakes after the earthquake. Most of the deeper landslides occurred in slopes underlain by limestone; 
however, a few occurred in weathered volcanic rocks. The largest of these deeper landslides was located about $20 \mathrm{~km}$ south of Petit-Goâve and had a volume of about 2,400,000 cubic meters $\left(\mathrm{m}^{3}\right)$.

\section{Numbers and Distribution}

Our inventory includes 23,567 triggered landslides (see map sheet). Landslides extended from the north coast to the south coast of the southwestern peninsula, where the epicenter was located. Landslide epicentral-distance limits were symmetrical about the epicenter to the southwest and the southeast at $58 \mathrm{~km}$. Figure 2 shows the spatial distribution of local landslide concentration (percentage area covered by landslides within each square kilometer). Two areas of highest local landslide concentration are apparent: one about $10 \mathrm{~km}$ east of the epicenter along the Rivière Momance within and south of the EPGFZ, and another about $20 \mathrm{~km}$ west-southwest of the epicenter south of Grand-Goâve. Both of these areas have local landslide concentrations exceeding 20 percent; the area along the Rivière Momance near the EPGFZ had the highest concentration at greater than 40 percent. These areas of highest local landslide concentration occurred along major river drainages where the steepest slopes are present.

\section{Geologic Units Involved in Landslides}

The predominant rock types in which landslides occurred in the area south of Port-au-Prince are Tertiary calcareous rocks (predominantly limestone) and Cretaceous weathered volcanic rocks (fig. 1). Cretaceous limestone also intermingles with Cretaceous volcanic rocks in the region surrounding the northwest-southeast oriented valleys of the Gauche and Grand-Goâve Rivers that extend from Jacmel on the southeast to Grand-Goâve on the northwest (fig. 1). The limestone ranges from moderately weathered hard rock to more deeply weathered and hydrothermally altered rock that is fractured and blocky (fig. 3). Rock falls and rock slides in these calcareous rocks failed along preexisting fractures and consist of cobble- to boulder-sized fragments. Thicknesses of falls and slides in the limestone typically ranged from 2 to $10 \mathrm{~m}$. Failures within the weathered volcanic rock generally were much thinner and occurred within the weathered regolith or colluvium; such failures ranged from $0.2 \mathrm{~m}$ to several meters in thickness (fig. 4).

Table 1 lists the geologic units, the area covered by landslides within each unit, the total area of each unit within the map area, and the percentage of each unit covered by landslides; this information is shown graphically in figure 5 . Figure $5 A$ shows that the two units having the highest numbers of landslides were the calcareous unit Ems (8,917 landslides) and the basaltic unit $\mathrm{Cb}$ (5,861 landslides). Although unit Ems had the greatest number of landslides and the highest local landslide concentration (42 percent in areas of abundant steep slopes), table 1 and figure $5 B$ show that the highest overall landslide concentration by far occurred in the Cretaceous limestone unit Cs (2.549 percent). This unit crops out at the western end of the fault-rupture zone and contains a dense concentration of landslides (see fig. 2 and map sheet). All other units had landslide concentrations less than 1 percent. Among calcareous units, Mi (0.885 percent), Ems (0.657 percent), Ep (0.647 percent), and O (0.639 percent) form the next tier of landslide concentrations. The two volcanic units had concentrations similar to these calcareous units: $\mathrm{Ca}(0.648$ percent $)$ and $\mathrm{Cb}$ (0.619 percent). These concentrations are broadly consistent with the findings of $\mathrm{Xu}$ and others (2014), who list landslide area percentages for their three highest concentrations as $\mathrm{Cs}$ ( 1.75 percent $), \mathrm{Mi}(0.84$ percent $)$, and $\mathrm{Ca}(0.72$ percent $)$. The overall landslide concentration in the study area was 0.564 percent.

Landslide numbers, areas, and concentrations with the geologic units are generalized into three rock types: alluvium, calcareous rocks, and volcanic rocks (table 2). Calcareous units accounted for 70 percent of the total number of landslides and 77 percent of the overall landslide area (table 2). Volcanic units accounted for 28 percent of the landslides and 23 percent of the landslide area. Landslides in alluvium were a negligible fraction of the landslides and landslide area. Because calcareous rocks are far more extensive than volcanic rocks, however, landslide concentrations in these rock types were nearly identical (0.631 and 0.621 percent, respectively).

\section{Topography}

The topography in Haiti on the peninsula south of Portau-Prince is characterized by upland plateaus dissected by steep canyons. Most of the landslides triggered by the earthquake occurred within or along these canyons. The distribution of slopes on which landslides occurred (fig. 5C) shows that the maximum number were on slopes of about $35^{\circ}$.

Although some landslides from this earthquake originated near the crests of ridges, most occurred within the steep inner gorges along rivers at some distance below the ridge crests. This contrasts with observations from some other worldwide earthquakes where triggered landslides were concentrated most heavily along ridge crests (Meunier and others, 2008). In many of the river drainages in Haiti, the steepest slopes are concentrated near the river channel.

\section{Seismic Shaking}

At the time of this earthquake, there were no seismic instruments in Haiti. The closest seismic instrument was located in the Dominican Republic within the abutment of a dam. The Dominican Republic occupies the eastern two-thirds of the island of Hispaniola. Using teleseismic body-wave data, coastal uplift/subsidence data from GPS measurements, and InSAR data, multiple models of the fault source and its slip have been constructed (Calais and others, 2010; Hayes and others, 2010; Symithe and others, 2013). These models show variations in 


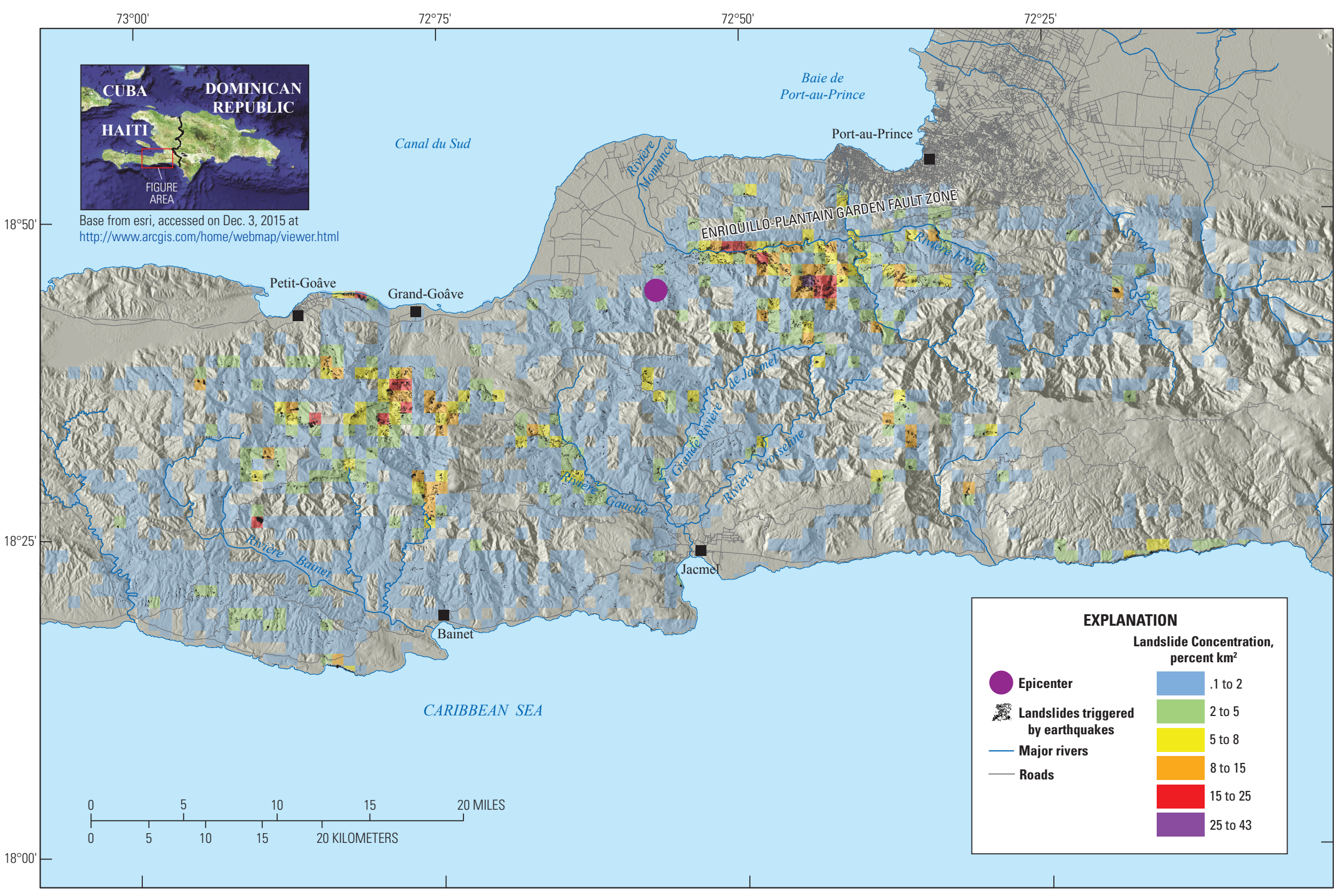

Base map data from a variety of sources (see pamphlet), accessed from http://hdds.usgs.gov/ between January 2013 and January 2014

Projection: Universal Transverse Mercator, zone 18: World Geodetic System 1984 (WGS 84); False easting 500000.0, false northing 0.0, central meridian -75.0

Figure 2. Map of landslide concentration $\left(p e r c e n t / \mathrm{km}^{2}\right)$ in the landslide-affected area 


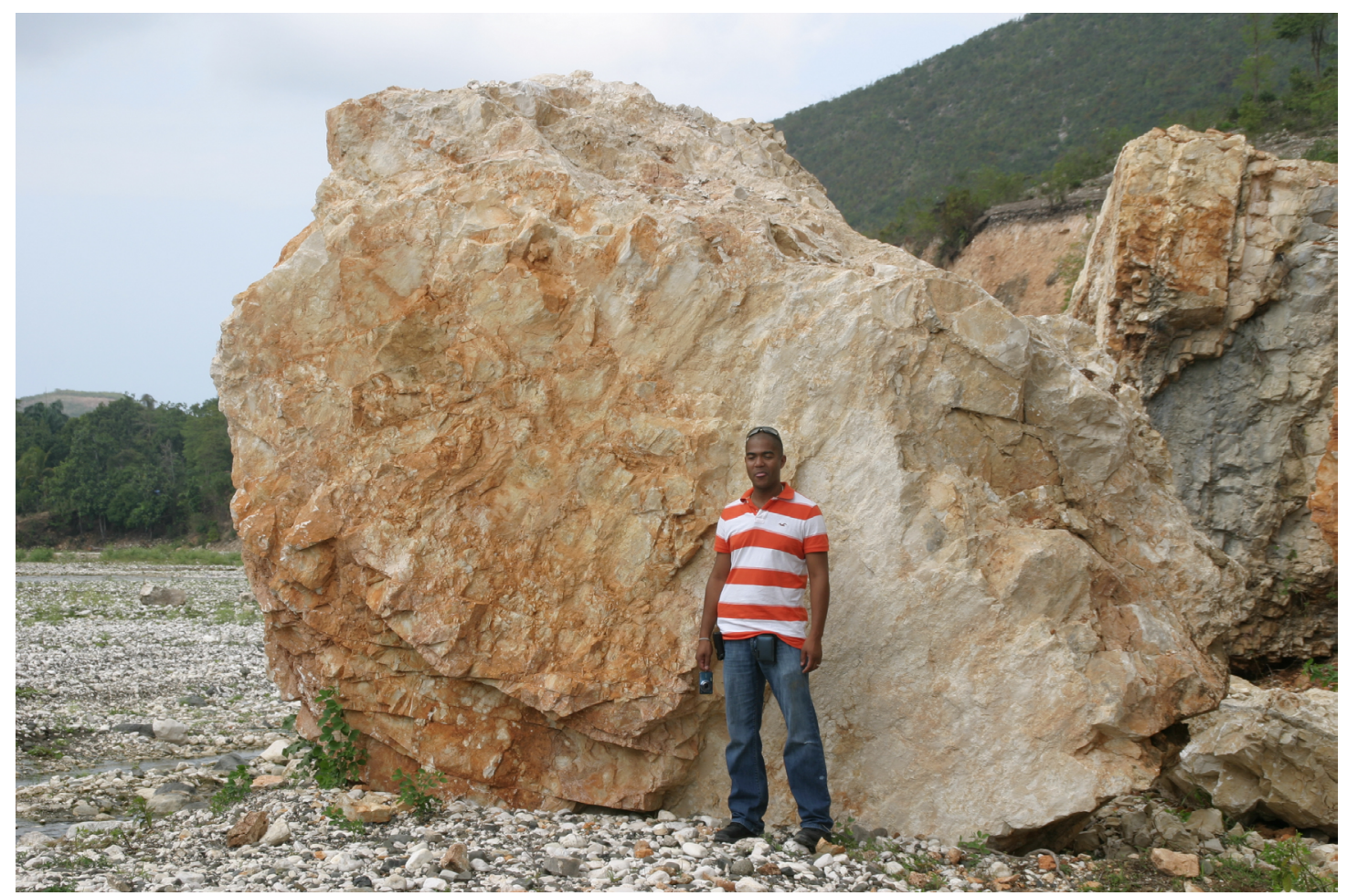

Figure 3. Rock fall composed of lower Miocene limestone boulders that have failed along preexisting fractures. Photograph taken along the Rivière Momance about 20 km west-southwest of Port-Au-Prince (see fig. 1). Photograph by R.W. Jibson, March 2010.

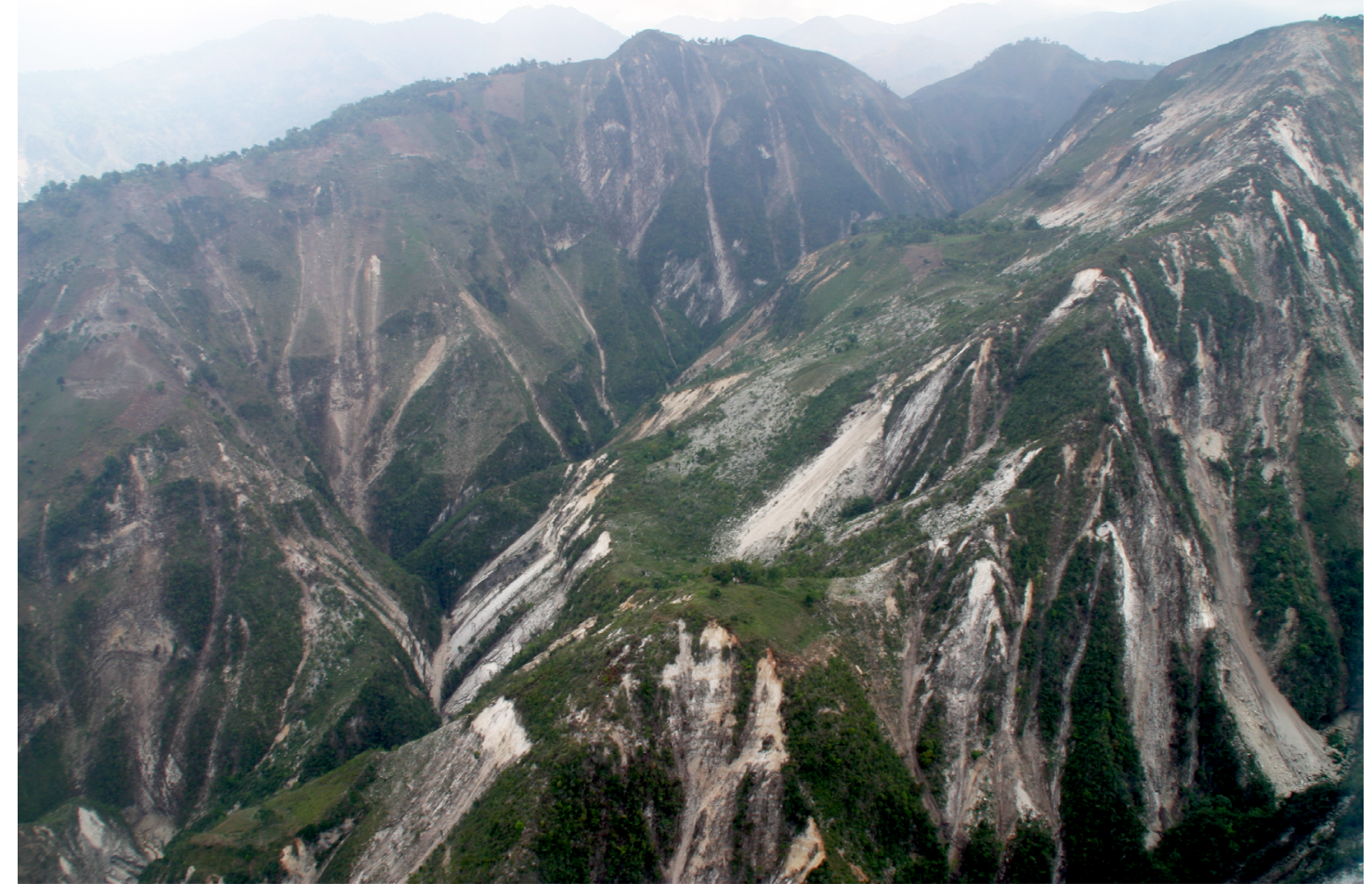

Figure 4. Shallow soil slides in weathered volcanic regolith within the Enriquillo-Plantain Garden fault zone. Landsides are visible as lighter colored, unvegetated areas. Photograph taken about $20 \mathrm{~km}$ southwest of PortAu-Prince (see fig. 2). Photograph by E.L. Harp, March 2010. 
Table 1. Areal distribution of earthquake-triggered landslides within geologic units in the study area.

[Square kilometers, $\mathrm{km}^{2}$; Geologic units from Bureau des Mines et de l’Energie (2005)]

\begin{tabular}{cccccc}
\hline Geologic unit' & Rock type & Number of landslides & $\begin{array}{c}\text { Area of landslides } \\
\left(\mathbf{k m}^{2}\right)\end{array}$ & $\begin{array}{c}\text { Area of geologic unit } \\
\text { within study area } \\
\left(\mathbf{k m}^{2}\right)\end{array}$ & $\begin{array}{c}\text { Percentage of unit } \\
\text { covered by } \\
\text { landslides }\end{array}$ \\
\hline $\mathrm{Qa}$ & Alluvium & 347 & 0.16 & 475.80 & 0.034 \\
$\mathrm{Qc}$ & Calcareous & 265 & 0.17 & 83.51 & 0.199 \\
$\mathrm{Qac}$ & Calcareous & 20 & 0.01 & 193.06 & 0.004 \\
$\mathrm{P}$ & Calcareous & 351 & 0.20 & 190.72 & 0.106 \\
$\mathrm{Ms}$ & Calcareous & 362 & 0.36 & 92.56 & 0.386 \\
$\mathrm{Mm}$ & Calcareous & 118 & 0.08 & 174.24 & 0.049 \\
$\mathrm{Mi}$ & Calcareous & 1,945 & 1.50 & 169.24 & 0.885 \\
$\mathrm{Es}$ & Calcareous & 25 & 0.06 & 29.03 & 0.214 \\
$\mathrm{O}$ & Calcareous & 683 & 0.73 & 114.12 & 0.639 \\
$\mathrm{Ems}$ & Calcareous & 8,917 & 9.87 & $1,502.58$ & 0.657 \\
$\mathrm{Ep}$ & Calcareous & 1,741 & 1.65 & 254.12 & 0.647 \\
$\mathrm{Pi}$ & Calcareous & 116 & 0.15 & 31.67 & 0.480 \\
$\mathrm{Cs}$ & Calcareous & 2,038 & 4.19 & 164.49 & 2.549 \\
$\mathrm{Cc}$ & Calcareous & 4 & 0.01 & 6.04 & 0.116 \\
$\mathrm{Ca}$ & Volcanic & 774 & 0.47 & 72.44 & 0.648 \\
$\mathrm{Cb}$ & Volcanic & 5,861 & 5.09 & 822.16 & 0.619 \\
\hline Total & & $\mathbf{2 3 , 5 6 7}$ & $\mathbf{2 4 . 6 9}$ & $\mathbf{4 , 3 7 5 . 7 8}$ & ${ }^{2} \mathbf{0 . 5 6 4}$ \\
\hline
\end{tabular}

${ }^{1}$ Units described in figure 1.

${ }^{2}$ The total percentage of unit covered by landslides is the total landslide area divided by the total study area. 

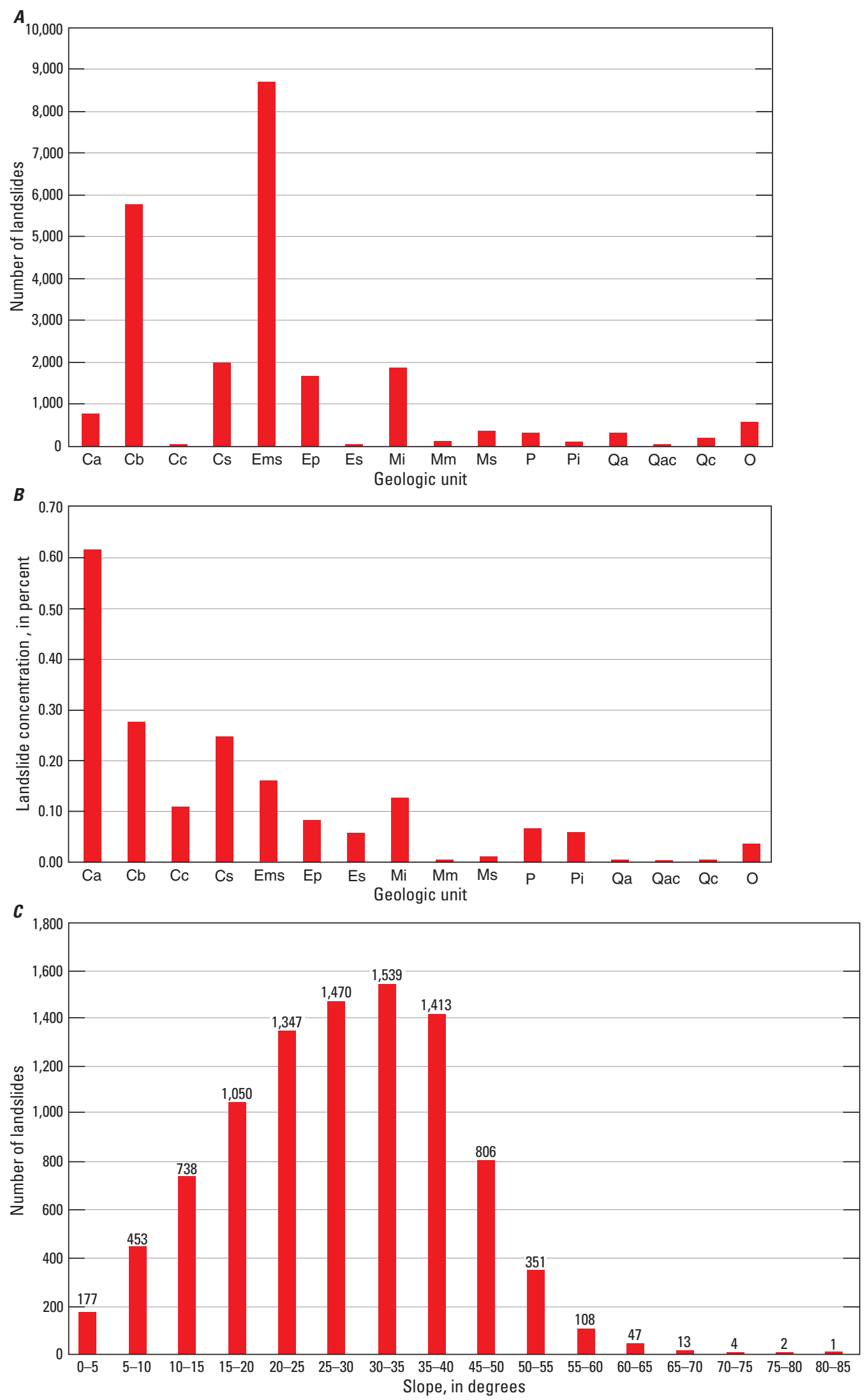

Figure 5. Histograms of triggered landslides with respect to geology and slope: $A$, Numbers of landslides within each geologic unit (refer to fig. 1); $B$, Landslide concentration within each geologic unit (geologic units defined in fig. 1); $C$, Number of landslides within $5^{\circ}$ slope ranges. 
Table 2. Areal distribution of earthquake-triggered landslides for different rock types in the study area.

[Square kilometers, $\mathrm{km}^{2}$ ]

\begin{tabular}{ccccc}
\hline Rock type & Number of landslides & $\begin{array}{c}\text { Area of landslides } \\
\left.\mathbf{( k m}^{2}\right)\end{array}$ & $\begin{array}{c}\text { Area of rock type within } \\
\text { study area } \\
\left(\mathbf{k m}^{2}\right)\end{array}$ & $\begin{array}{c}\text { Percentage of rock } \\
\text { type covered by } \\
\text { landslides }\end{array}$ \\
\hline Alluvium & 347 & 0.16 & 475.80 & 0.034 \\
Calcareous & 16,585 & 18.97 & $3,005.39$ & 0.631 \\
Volcanic & 6,635 & 5.56 & 894.59 & 0.621 \\
\hline Total & $\mathbf{2 3 , 5 6 7}$ & $\mathbf{2 4 . 6 9}$ & $\mathbf{4 , 3 7 5 . 7 8}$ & $\mathbf{1 0 . 5 6 4}$ \\
\hline
\end{tabular}

${ }^{1}$ The total percentage of rock type covered by landslides is the total landslide area divided by the total study area.

the coseismic slip of the fault that could have influenced the spatial distribution of the landslides triggered by the earthquake. The model constructed by Hayes and others (2010) for the Léogâne fault plane, upon which 80 percent of the moment release occurred (fig. 6), indicates that the maximum fault slip occurred at the eastern edge of the fault source, approximately $12 \mathrm{~km}$ from the area of the highest local landslide concentration along the Rivière Momance near and just south of the EPGFZ. Local landslide concentration immediately above the area of maximum fault slip was not high because the topography in that area is fairly flat. The other area of high landslide concentration south of Grand-Goâve is $8 \mathrm{~km}$ south-southwest of the westernmost slip maxima (fig. 6). The slip vectors in the fault-slip model (fig. 6) point in a south to south-southwest direction in the vicinity of the region of maximum slip near the eastern edge of the fault-source model; slip vectors near the westernmost slip maxima point west-southwest. The distances from the area of maximum fault slip to the farthest landslides are $42 \mathrm{~km}$ to the southeast and $62 \mathrm{~km}$ to the southwest.

Most of the earthquake-triggered landslides lie south of the fault source and epicenter, on the footwall of the Léogâne fault, in the general direction of thrust movement on the fault. This contrasts with other worldwide thrust earthquakes where the greatest numbers of landslides and the strongest ground motions were concentrated on the hanging wall (Abrahamson and Somerville, 1996; Harp and Jibson, 1996; Allen and others, 1998; Shabestari and Yamazaki, 2003; Chang and others, 2004). However, the landslide distribution for this earthquake is strongly constrained by the distribution of steep topographythe area north of the Léogâne fault, on the hanging wall, consists primarily of a fairly flat coastal plain truncated by the coastline with relatively sparse steep slopes. Thus, the relative lack of susceptible topography on the hanging wall constrains the landslide distribution mostly to the footwall. Other faultslip models (Symithe and others, 2013) are similar to that of Hayes and others (2010) except that they consist of two adjacent segments located slightly south of the fault source of Hayes and others (2010). The slip vectors (see fig. 7, modified from Symithe and others, 2013) are similar in magnitude and direction in the eastern segment to those in the model by Hayes and others (2010); in the western segment, however, the vectors trend more southerly than do those in the model of Hayes and others (2010) (fig. 6). The model in figure 7 is one of three constructed by Symithe and others (2013) for different weights of GPS, InSAR, and uplift data. In the other two models of Symithe and others (2013), the slip vectors in the western segment trend nearly west. Although the high local concentration of landslides in the Rivière Momance area is close (10-12 km) to the areas of maximum slip shown on both models, neither the Hayes and others (2010) nor the Symithe and others (2013) model have vectors that point directly toward this high landslide concentration. However, the Symithe and others (2013) version that we show in figure 7 does show slip vectors in the western segment that point directly toward the high local concentration of landslides south of Petit-Goâve, whereas the Hayes and others (2010) model shows vectors in the western portion of the model pointing more westward. In view of the south to southwest directivity of the coseismic slip on the Léogâne fault, especially that shown in figure 7, it is possible that the distribution of the majority of landslides to the south of the thrust fault in this area is in part a response to this directivity.

The lack of strong-motion instruments in the country at the time of the earthquake resulted in no local instrumental control on the pattern of ground shaking. Input into the local ground-shaking patterns displayed in ShakeMap are from the normal parameters used by ShakeMap (Worden and others, 2010) such as broadband or strong-motion far-field stations of the Global Seismic Network (GSN), modified Mercalli intensities (MMI) from "Did You Feel It" (DYFI) compiled by the USGS National Earthquake Information Center (http://earthquake.usgs.gov/earthquakes/eventpage/ usp000h60h\#impact_dyfi), attenuation models based on the distance from the fault, and estimated site amplification effects. The ShakeMap (version 2) estimate of ground shaking from the earthquake overlain on the landslide concentrations from figure 2 is shown in figure 8. PGA patterns shown here are fairly crude estimates of the ground shaking. The relatively symmetrical "race track" shape of the PGA contours around the fault source are broadly consistent with the decrease in landslide concentration, but this rather generic estimate of the regional ground motion fails to explain local differences in landslide concentration that are likely controlled by variations in lithology, topography, and shaking. 


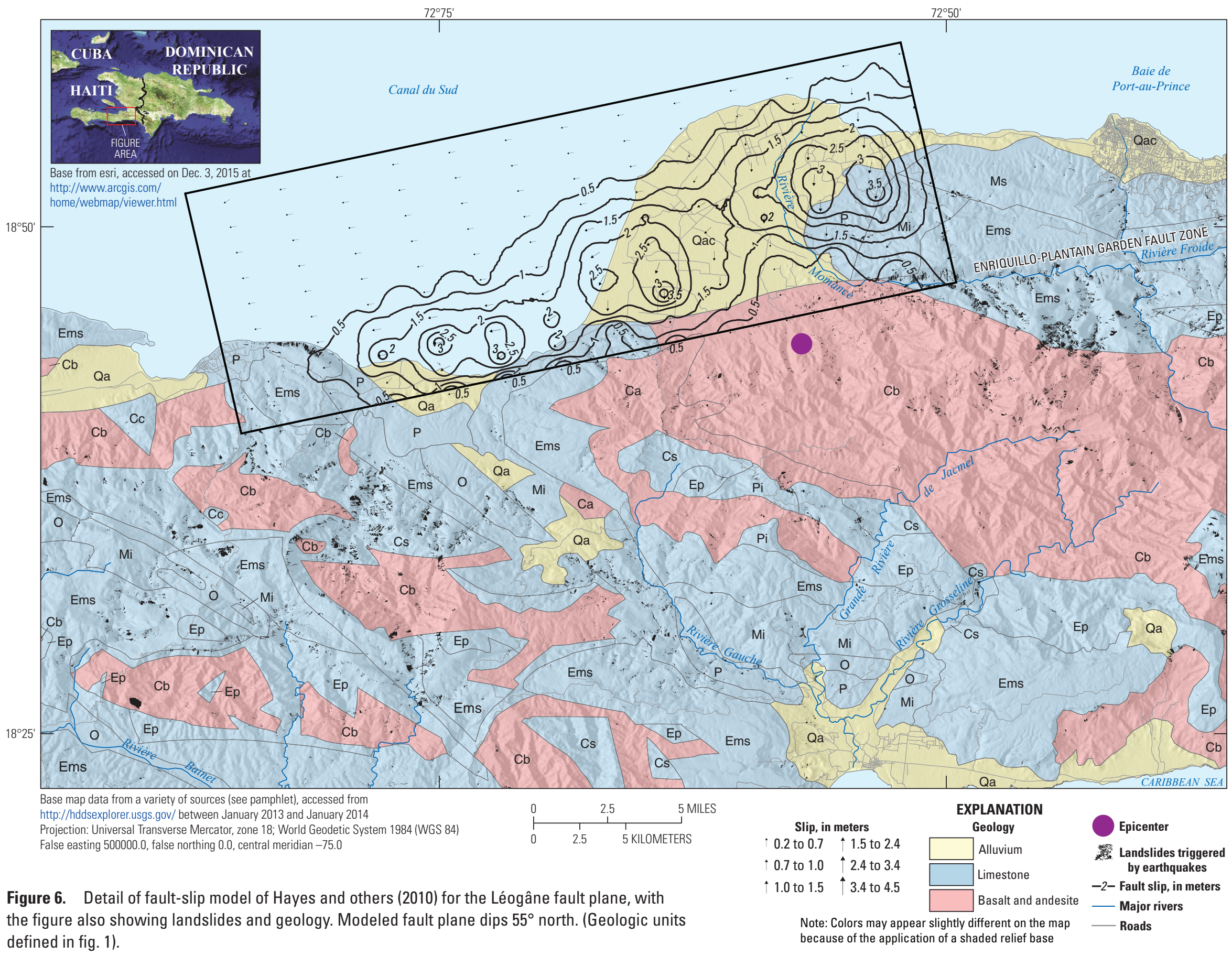




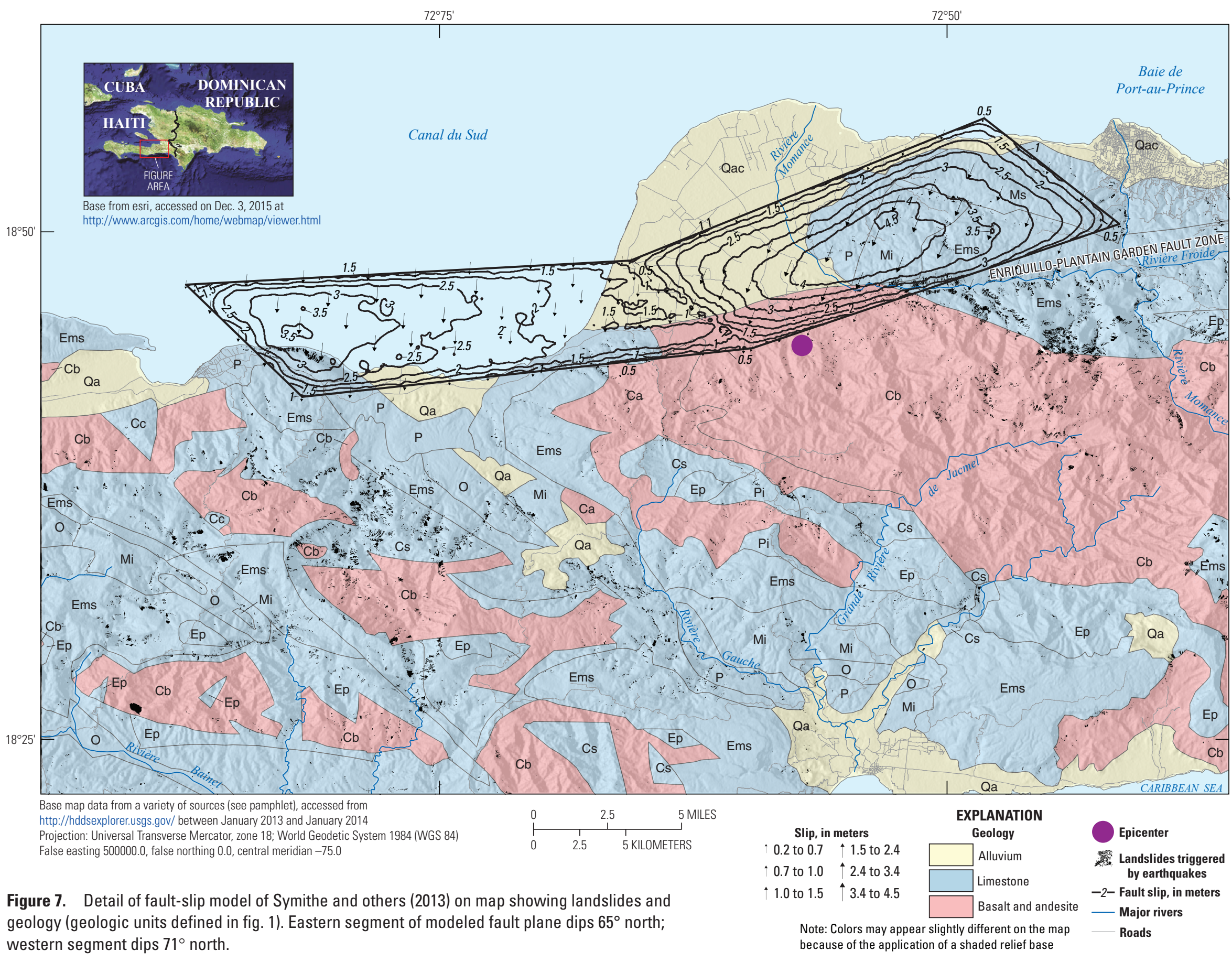




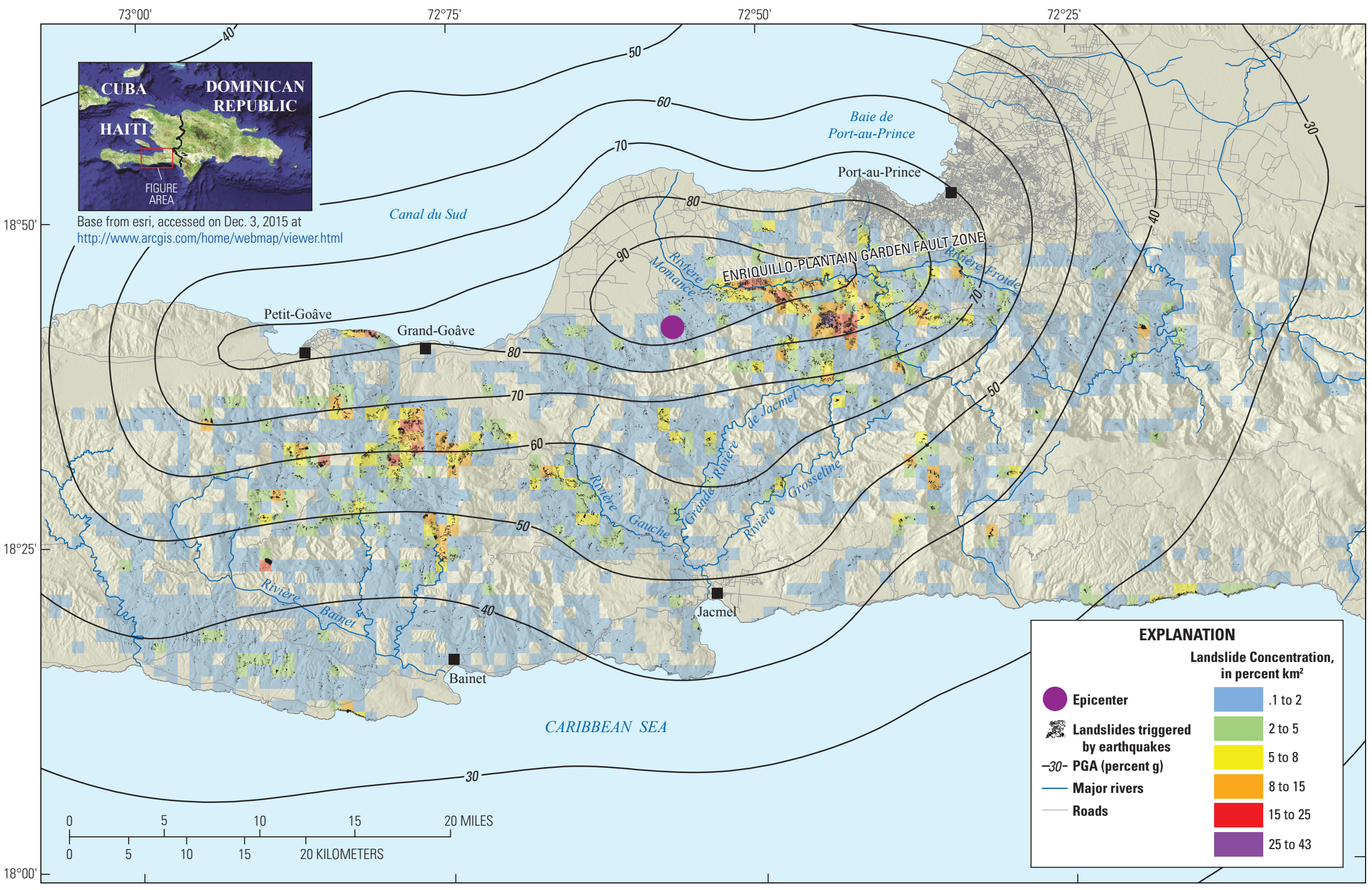

Base map data from a variety of sources (see pamphlet), accessed from http://hddsexplorer.usgs.gov/ between January 2013 and January 2014

Projection: Universal Transverse Mercator, zone 18; World Geodetic System 1984 (WGS 84); False easting 500000.0, false northing 0.0, central meridian -75.0

Figure 8. Map of landslide concentration overlain by ShakeMap contours of peak ground acceleration (PGA) from the earthquake (see http://earthquake.usgs.gov/earthquakes/ eventpage/gcmt20100112215310\#impact_shakemap) (U.S. Geological Survey, 2010b). 


\section{Discussion}

The relation of seismically triggered landslides to topography has been well known for decades. The locations of landslides triggered by earthquakes on steep slopes, ridges, and promontories have been documented in numerous publications (Harp and others, 1981; Harp and Keefer, 1990; Harp and Jibson, 1996; Ashford and others, 1997; Meunier and others, 2008). The distribution of landslides triggered by this earthquake follows similar general patterns.

The effect of material-property differences in rock and soil in influencing the patterns of seismically triggered landslides also has been well established (Harp and others, 1981; Harp and Keefer, 1990; Chigira and Yagi, 2006; Wang and others, 2007; Lee and others, 2008; Yagi and others, 2009; Dreyfus and others, 2013). We lack data on the shear strengths of the materials in our study area and thus cannot quantify this effect in this earthquake.

The effects of shaking variations on seismically triggered landslide distributions have been discussed in previous research with respect to both topographic amplification and the correlation of landslides with the hanging wall of a thrust earthquake (Harp and others, 1981; Abrahamson and Somerville, 1996; Harp and Jibson, 1996, 2002; Allen and others, 1998; Shabestari and Yamazaki, 2003; Chang and others, 2004). The effect of local variation of ground shaking during the Haiti earthquake on the landslide distribution cannot be assessed in detail because of the absence of any seismic instruments in the country at the time of the earthquake. However, finite-fault modeling and ShakeMap allow us to make some broad correlations between landslide distribution and ground motion.

\section{Summary and Conclusions}

Field reconnaissance shortly after the earthquake coupled with detailed examination of pre- and post-earthquake imagery have allowed us to produce a map showing 23,567 landslides triggered by the 2010 Haiti earthquake. In this report, we present a description and preliminary evaluation of the landslide distribution with respect to lithology, topography, models of fault slip, and strong shaking estimated by ShakeMap. Some general observations are as follows:

- Most of the landslides, as well as the highest local landslide concentrations, are within calcareous units (Ems and Cs), which have the greatest areal extent and the steepest slopes within the landslide-affected area. Overall landslide concentrations, however, are similar in calcareous and volcanic units.

- Although some landslide sources for this earthquake are located on the crests of slopes, most occur within the steep drainages along rivers and at some distance below the ridge crests.
- No clear relation is apparent between the landslide distribution and the fault-slip models. The greatest local landslide concentrations along the Rivière Momance near the EPGFZ are 10-12 $\mathrm{km}$ from the maximum fault slip in the fault-slip models; the westernmost high local landslide concentration south of GrandGoâve is about $8 \mathrm{~km}$ from the zones of maximum slip in the western part of the slip models.

- Unlike in many other thrust earthquakes, the large majority of landslides occurred on the footwall of the thrust fault. This is primarily because of the lack of susceptible slopes on the hanging wall.

- The lack of strong-motion instruments in Haiti precludes making a detailed analysis of the relation between landslide distribution and ground motion.

\section{References Cited}

Abrahamson, N.A., and Somerville, P.G., 1996, Effects of hanging wall and footwall on ground motions recorded during the Northridge earthquake: Bulletin of the Seismological Society of America, v. 86, no. 1B, p. S93-S99.

Allen, C.R., Brune, J.N., Cluff, L.S., and Barrows, A.G., 1998, Evidence for unusually strong near-field ground motion on the hanging wall of the San Fernando fault during the 1971 earthquake: Seismological Research Letters, v. 69, no. 6, p. 524-531.

Ashford, S.A., Sitar, Nicholas, Lysmer, John, and Deng, Nan, 1997, Topographic effects on the seismic response of steep slopes: Bulletin of the Seismological Society of America, v. 87 , no. 3, p. 701-709.

Bureau des Mines et de l'Énergie, 2005, Carte Geologique de la République d'Haïti: République d'Haïti, Bureau des Mines et de l'Energie, scale 1:250,000 [In French]. [Also available at www.bme.gouv.ht/carte/notice.pdf.]

Calais, Eric, Freed, Andrew, Mattioli, Glen, Amelung, Falk, Jónsson, Sigurjón, Jansma, Pamela, Hong, S.-H., Dixon, Timothy, Prépetit, Claude, and Momplaiser, Roberte, 2010, Transpressional rupture of an unmapped fault during the 2010 Haiti earthquake, Nature Geoscience, v. 3, p. 794-799.

Cavallo, E.A, Powell, Andrew, and Becerra, Oscar, 2010, Estimating the direct economic damage of the earthquake in Haiti: The Economic Journal, v. 120, is. 546, p. F298-F312, DOI: $10.1111 / \mathrm{j} .1468-0297.2010 .02378 . x$.

Chang, T.Y., Cotton, Fabrice, Tsai, Y.B., and Angelier, Jacques, 2004, Quantification of hanging-wall effects on ground motion-Some insights from the 1999 ChiChi earthquake: Bulletin of the Seismological Society of America, v. 94, no. 6, p. 2186-2197. 
Chigira, Masahiro, and Yagi, Hiroshi, 2006, Geological and geomorphological characteristics of landslides triggered by the 2004 Mid Niigata Prefecture earthquake in Japan: Engineering Geology, v. 82, p. 202-221.

Dreyfus, Daniel, Rathje, E.M., and Jibson, R.W., 2013, The influence of different simplified sliding-block models and input parameters on regional predictions of seismic landslides triggered by the Northridge earthquake: Engineering Geology, v. 163, p. 41-54.

Gorum, Tolga, van Westen, C.J., Korup, Oliver, van der Meijde, Mark, Fan, Xuanmei, and van der Meer, F.D., 2013, Complex rupture mechanism and topography control symmetry of mass-wasting pattern, 2010 Haiti earthquake: Geomorphology, v. 184, p. 127-138.

Harp, E.L., and Jibson, R.W., 1996, Landslides triggered by the Northridge, California, earthquake: Bulletin of the Seismological Society of America, v. 86, no. 1B, S319-S332.

Harp, E.L., and Jibson, R.W., 2002, Anomalous concentrations of seismically triggered rock falls in Pacoima Canyon-Are they caused by highly susceptible slopes or local amplification of seismic shaking?: Bulletin of the Seismological Society of America, v. 92, p. 3180-3189.

Harp, E.L., and Keefer, D.K., 1990, Landslides triggered by the earthquake, in Rymer, M.J., and Ellsworth, W.L., eds., The Coalinga, California, earthquake of May 2, 1983: U.S. Geological Survey Professional Paper 1487, p. 335-347, $1 \mathrm{pl}$. [Also available at http://pubs.er.usgs.gov/publication/ pp1487.]

Harp, E.L., Jibson, R.W., and Dart, R.L., 2013, The effect of complex fault rupture on the distribution of landslides triggered by the 12 January 2010, Haiti earthquake, in Margottini, Claudio, Canuti, Paolo, and Sassa, Kyoji, eds., Landslide Science and Practice, Proceedings of the Second World Landslide Forum, v. 5, p. 157-161: Berlin, Heidelberg, Springer-Verlag, doi: 10.1007/978-3-642-31427-8_20.

Harp, E.L., Wilson, R.C., and Wieczorek, G.F., 1981, Landslides from the February 4, 1976, Guatemala earthquake: U.S. Geological Survey Professional Paper1204-A, p. 1-35, $2 \mathrm{pl}$. [Also available at http://pubs.er.usgs.gov/publication/ pp1204A.]

Hayes, G.P., Briggs, R.W., Sladen, Anthony, Fielding, E.J., Prentice, Carol, Hudnut, Kenneth, Mann, Paul, Taylor, F.W., Crone, A.J., Gold, Ryan, Ito, Takeo, and Simons, Mark, 2010, Complex rupture during the 12 January 2010 Haiti earthquake: Nature Geoscience, v. 3, p. 800-805.

Jibson, R.W., and Harp, E.L., 2011, Field reconnaissance report of landslides triggered by the January 12, 2010, Haiti earthquake: U.S. Geological Survey Open-File Report 2011-1023, 18 p. [Also available at http://pubs.er.usgs.gov/ publication/ofr20111023.]
Keefer, D.K., 1984, Landslides caused by earthquakes: Geological Society of America Bulletin, v. 95, p. 406-421.

Kolbe, A.R., Hutson, R.A., Shannon, Harry, Trzinski, Eileen, Miles, Bart, Levitz, Naomi, Puccio, Marie, James, Leah, Noel, J.R., and Muggah, Robert, 2010, Mortality, crime, and access to basic needs before and after the Haiti earthquake: Medicine, Conflict, and Survival, v. 26, p. 281-297.

Lee, C.T., Huang, C.C., Lee, J.F., Pan, K.L., Lin, M.L., and Dong, J.J., 2008, Statistical approach to earthquake-induced landslide susceptibility: Engineering Geology, v. 100, p. $43-58$.

Meunier, Patrick, Hovius, Niels, and Haines, J.A., 2008, Topographic site effects and the location of earthquake induced landslides: Earth and Planetary Science Letters, v. 275, p. 221-232.

Shabestari, K.T., and Yamazaki, Fumio, 2003, Near-fault spatial variation in strong ground motion due to rupture directivity and hanging wall effects from the Chi-Chi earthquake: Earthquake Engineering and Structural Dynamics: v. 32, p. 2197-2219.

Symithe, S.J., Calais, Eric, Haase, J.S., Freed, A.M., and Douilly, Roby, 2013, Coseismic slip distribution of the 2010 M 7.0 Haiti earthquake and resulting stress changes on regional faults: Bulletin of the Seismological Society of America, v. 103, p. 2326-2343.

U.S. Geological Survey, ASTER 1 arc-second for scene ASTGDEMV2_0N18W073: U.S. Geological Survey Earth Resources Observation and Science (EROS) Center, accessed October 2011, at http://eros.usgs.gov/\#/Find_Data/ Products_and_Data_Available/Aster. Link no longer active. The current link to find such data is as follows: http:// reverb.echo.nasa.gov/reverb/\#utf8=\%E2\%9C\%93\&spatial_ map $=$ satellite \&spatial_type=rectangle.

U.S. Geological Survey, 2010a, Magnitude 7.0-Haiti region 2010 January 12 21:53:10 UTC: U.S. Geological Survey, Earthquake hazards program. [Also available at http:// www.earthquake.usgs.gov/earthquakes/eqinthenews/2010/ us2010rja6/.]

U.S. Geological Survey, 2010b, ShakeMap, M7.0—Haiti region: U.S. Geological Survey, Earthquake hazards program. [Also available at http://earthquake.usgs.gov/earthquakes/eqinthenews/2010/us2010rja6/.]

Varnes, D.J., 1978, Slope movement types and processes, in Schuster, R.L., and Krizek, R.J., eds., Landslides-Analysis and Control: Washington, D.C., National Research Council, Transportation Research Board, Special Report 176, p. 11-33.

Wang, H.B., Sassa, Kyoji, and Xu, W.Y., 2007, Analysis of a spatial distribution of landslides triggered by the 2004 Chuetsu earthquakes of Niigata Prefecture, Japan: Natural Hazards, v. 41, p. 43-60. 
Worden, C.B., Wald, D.J., Allen, T.I., Lin, K.-W., Garcia, Daniel, and Cua, Georgia, 2010, A revised ground-motion and intensity interpolation scheme for ShakeMap: Bulletin of the Seismological Society of America, v. 100, p. 3083-3096.

Xu, Chong, Shyu, J.B.H., and Xu, X.-W., 2014, Landslides triggered by the 12 January $2010 \mathrm{Mw} 7.0$ Port-au-Prince, Haiti, earthquake - Visual interpretation, inventory compiling and spatial distribution statistical analysis: Natural Hazards and Earth System Sciences, v. 14, p. 1789-1818.

Yagi, Hiroshi, Sato, Go, Higaki, Daisuke, Yamamoto, Miki, and Yamasaki, Takanari, 2009, Distribution and characteristics of landslides induced by the Iwate-Miyagi Nairiku earthquake in 2008 in Tohoku District, northeast Japan: Landslides, v. 6, p. 335-344.

Publishing support provided by:

Denver Publishing Service Center

For more information concerning this publication, contact:

Center Director, USGS Geologic Hazards Science Center

Box 25046, Mail Stop 966

Denver, CO 80225

(303) 273-8579 



\section{$\frac{\mathbb{3}}{\mathrm{C}}$}

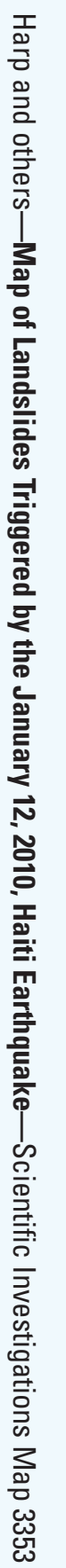

